Check for updates

Washington, DC

Cite this as: BMJ 2022;376:0375 http://dx.doi.org/10.1136/bmj.0375 Published: 11 February 2022

\section{Covid-19: Pandemic has harmed cancer outcomes and widened inequalities, report finds}

\author{
Bob Roehr freelance journalist
}

The covid-19 pandemic has impaired referrals for preliminary cancer diagnoses and led to an $11 \%$ increase in patients diagnosed with inoperable or metastatic cancer in the US in 2020, a new report has found.

The report by the American Association for Cancer Research (AACR) on the impact of covid-19 on cancer research and patient care, ${ }^{1}$ released on 9 February, also noted that nearly 10 million patients missed cancer screenings during the first six months of the year, resulting in later diagnoses and poorer outcomes.

In a briefing to discuss the report organised by AACR, Philadelphia oncologist Ana Marie Lopez drew attention to the finding that the pandemic had struck medically underserved communities hardest, particularly people of colour.

"This pandemic has laid bare the inequities in cancer care," she said. "It has caused the highest drop in life expectancy that we have seen since the second world war. For Black people, that has been twice as much as for whites." She used the example of surgery for prostate cancer, which declined by $91 \%$ for Black patients compared with $17.4 \%$ for white people.

The report noted that patients with cancer are among the 7-10 million Americans with weakened immune systems who respond less well both to vaccination and to treatment if they become infected. Larry Saltzman, a patient with lymphoma, said he had received the jab four different times and still had no detectable level of antibody protection.

Much cancer treatment is conducted as a clinical trial and Saltzman urged greater flexibility in how those studies are organised. He said he was "lost to follow-up for 18 months" because it was deemed too risky for him to fly for follow-up visits for the T cell therapy he had begun. Saltzman argued that much of that follow-up, such as imaging scans, could have been performed nearer to where he lives and sent to the study centre.

AACR said a lot of research was shut down and some laboratories changed focus to support pandemic efforts. This was particularly harmful to investigators early in their careers.

The association is calling for an increase in funding for the current fiscal year. It wants an additional \$3bn for the National Institutes of Health and $\$ 1.1 \mathrm{bn}$ for the National Cancer Institute, or \$46.4bn and \$7.6bn respectively for the fiscal year. It also wants to see an expansion of Medicaid, the health insurance programme for Americans with low incomes that is funded primarily by the federal government but with some contributions and administration by the states.

The Biden administration announced a cancer "moonshot 2.0" on 2 February with the goal of increasing screening and improving treatment, but with no additional funding. It was to be led by science adviser Eric Lander, but he resigned after a few days over charges that he had abused his staff. The BMJ asked AACR how these charges would affect what they seek but had not received a reply at the time of publication.

1 AACR report on the impact of covid-19 on cancer research and patient care. www.aacr.org/professionals/research/aacr-covid-19-and-cancer-report-2022.

This article is made freely available for personal use in accordance with BMJ's website terms and conditions for the duration of the covid-19 pandemic or until otherwise determined by BMJ. You may download and print the article for any lawful, non-commercial purpose (including text and data mining) provided that all copyright notices and trade marks are retained. 